\title{
On the Emerging Polish Diaspora and its Development in Siberia in the First Half of the $19^{\text {th }}$ Century
}

\author{
Vladimir N. Shaidurov* \\ National Mineral Resources \\ Mining University 'Gornyi' \\ 2, 21 ${ }^{\text {st }}$ Line, Vasil'evskii Island, \\ St. Petersburg, 199106, Russia
}

Received 17.02.2016, received in revised form 22.04.2016, accepted 23.06.2016

The Russian and Polish historical sciences focus closely on studying the ways that the Polish diaspora emerged and evolved outside areas where they traditionally resided. Polish communities actively formed as the government had implemented its punitive policies since the late 13th century. One of the areas settled by many natives of Poland was Siberia. While historiography traditionally devotes much attention to the study of the Polish community in the second half of the 19th century, there are few works dealing with the community's initial period in various Siberian provinces (guberniya). As a result, the article based on a variety of archival data is aimed at defining essential features characteristic of the Siberian Polish diaspora in the pre-reform period before the 1850s 'Great Reforms'.

Keywords: Polish community, Siberia, Tobol'sk province, Tomsk province, pre-reform period, 19th century, Polish uprisings, exile, police surveillance, economic and household activities.

DOI: 10.17516/1997-1370-2016-9-10-2496-2506.

Research area: history.

\section{Introduction}

Russian historical studies have long been interested in the Siberian multi-ethnic society formation process. The historical backgrounds of certain ethnic communities as well as their economic, social and political activities have been studied through various historical approaches both in the pre-revolutionary period and in the Soviet times. However, no comprehensive description of Siberian communities has been given in scientific literature so far.
One of historiographical peculiarities is that the overwhelming majority of researchers concentrated on a number of aspects, namely, addressing 'the Polish question' under the rule of tsars Nicholas I and Alexander II, defining Poles' place and their role in the national liberation and revolutionary movements, describing Poles in exile and hard labour. While these issues were analysed, as a rule, at a national level, locally emerging Polish communities remained outside the field of historical studies.

(C) Siberian Federal University. All rights reserved

* Corresponding author E-mail address: elada@spmi.ru 
Although the Siberian Polish diasporahas had a long history, the scope of its historiographical research cannot compete with the number of works on German and Jewish communities in the region. An analysis of theoretical sources on the subject suggests that while Russian and Polish scholars mainly studied the Siberian Polish community in the second half of the 19th century they did not write much about its life in the previous period. However, there are several works handling various sides of Poles' lives in the prereform years (Maksimov, 1900; Gerasimov, 1918; Shostakovich, 1995; Fil', 2002; Skubnevskii, 2009; Shaidurov, 2009; Shostakovich, 2009, et al). First of all, it is necessary to emphasize S. Maksimov's work Siberia and Hard Labour among them that was reprinted many times. According to B. Shostakovich, the book remained a study that all the subsequent generations of scholars until the late 1950s referred to (Shostakovich, 1995, 33).

\section{Statement of the problem and its solutions}

The proposed article determines the main stages of the Polish diaspora development in Western Siberia, reveals their specific features, analyses the civil status of Poles, and characterizes the most important sources of their welfare and types of economic activities they were involved in in the early $19^{\text {th }}$ century.

The paper is predominantly based on archival documents available in the Russian State Historical Archives (St. Petersburg), Tobol'sk State Archives (Tobol'sk), and published materials (legislative acts, regulations and memoirs). The latter include a source worth mentioning, that is memoirs by Ju. Rucinski published in 2009 under the title of Konarshchik (konarshchik is a member of the revolutionary Union of the Polish people from the Kingdom of Poland movement led by Szymon Konarski). The book portrays the exiled Poles going across Siberia to Nerchinsk works and their life there, as well as compulsory labour between the late 1830 s and early 1840 s.

\section{Discussion}

The first Poles came to Siberian towns in the 17th century. Most of them belonged to the prisoners captured in Polish-Russian wars. Historical studies reveal administrative and military correspondence concerning the question of captive Poles, Lithuanians, 'German people', Circassians, and Jews (Feld'man, 2005: 21). The first Siberian Pole was Nikifor Chernigovskii mentioned in Siberian chronicles (Maksimov, 1900: 326). In historical sources, his name is associated with opening up lands near the Amur River.

Under the 1619 Truce of Deulino and 1667 Truce of Andrusovo (the 1667 and 1672 Moscow treaties), Russia and the PolishLithuanian Commonwealth exchanged prisoners of war and sent Poles back to their homeland ${ }^{1}$. As a result, the Siberian Polish diaspora almost disappeared by the next century after brief existence. The disappearance was also contributed through policies regarding Polish and Lithuanian captives in Siberia implemented by the Russian government. According to S. Maksimov, these people, along with Moscow Streltsy were conscripted into the Cossacks and hence 'completely disappeared' in the social class (Maksimov, 1900: 327). Despite this, some of the Poles left their mark in the $17^{\text {th }}$ century history. For example, Jurii Kryzhanovskii was the fur tribute collector (yasaq) from the Tungus indigenous people of central and south-eastern Siberia in 1677. His illegal actions provoked so much concern and protest that the local people besieged the town of Okhotsk. That incident was followed by an inquiry that revealed numerous abuses by Kryzhanovskii. Afterwards he was sentenced to knout flogging and transported to Daur fortified town (ostrog, a Siberian type 
of a fortified settlement for quartering troops surrounded with a stockade) (Ibid).

The late $18^{\text {th }}$ and mid- $19^{\text {th }}$ centuries brought about the growing number of Poles related to the exiled members in the Polish liberation movement to the region. This period is divided into several stages.

The first period started in the mid-90s of the $18^{\text {th }}$ century. It was at that time when the part of Polish confederates was exiled to Nerchinsk works in Siberia. For instance, Decembrist N. Lorer wrote in his memoirs about General S. Leparskii who was a lieutenant (poruchik) in 1791 and escorted Polish prisoners. He performed this task so efficiently that his name was well-known in the whole army (Lorer, 1988: 406-407). The first month of Paul I's reign already witnessed the beginning of the amnesty announced according to the signed edict (imennoi ukase) of 29 November, 1796. The edict ordered the release of all prisoners who "were captured in the Polish uprisings and sentenced to punishment, prison and exile'2. The responsibility for administering the monarch's will was allocated to the Senate which, for its part, was to pass corresponding ordinances to governors and district judges (zemskii judge is a judge and state official in a district, a provincial subdivision). In fact, not all former confederates had an opportunity to return to their initial place of residence or leave Russia. It was necessary sometimes for St. Petersburg to interfere. For example, the 1797 order by the Senate Prosecutor General Aleksei Kurakin released several insurgents in the 1794 uprising from the Siberian exile. Still, some of them, including Joseph Teriasevich were hunted for by the Tobol'sk police throughout the province ${ }^{3}$.

Under the reign of Alexander I, Poles were still exiled to Siberia. At the same time the period in the Polish diaspora's history had a peculiarity, namely, most natives of the Kingdom of Poland, who were forcibly sent to Siberia, belonged to the 'common culprits convicted of criminal offences' (Maksimov, 1900: 340).

The 1830s saw a fresh inflow of Poles to Siberia. As it was the case earlier, the upsurge was originated from displacement. However, this time, most of the displaced were veterans of the 1830-1831 Polish-Russian war and the members of various secret societies, e.g. The Commonwealth of the Polish People, that emerged in the Kingdom of Poland after the uprising suppression (Shostakovich, 2009: 304).

It was those years that gave rise to a legal foundation for political exile. Thus, the period witnessed a number of documents formulated that sealed the fate of the 1830-1831 uprising participants. The most important papers included a resolution On the complete elimination of the personnel of the former Polish army of February 14, 1832, an edict On the uprising that broke out in three uezds of the Vilna province and on convicting all the aristocrats or Polish gentry who took part in that uprising under the field criminal law of 22 March, 1831, and Regulations on prisoners of war and defecting Polish soldiers of 31 May, 1831. Moreover, the Poles convicted for their involvement in the November uprising and national liberation movement in the 184050 s were subjected to the 1826 regulations that were reviewed in December 1834. The above mentioned documents determined the future of the captive Poles. Men were to serve in Siberian border battalions and boys became liable for future military service (cantonists) ${ }^{4}$.

During their captivity and transportation to Siberian destinations, prisoners of war were provided with food rations and monetary allowances dependent on their military ranks before the 1830 events. It is clear that the decision was purely pragmatic. In particular, its goal was to replenish remote Caucasus and Siberian garrisons by the soldiers physically fit for the military service in harsh environmental conditions 
(Samovich, 2011: 163). In 1839, the allowance for the exiles was 3 kopecks (6 groshes) a day. The money was quite enough as food prices were very low in Siberia. For example, a group of 8 members of the Union of the Polish people (konarshchiks) transported in 1839 received the money and it was sufficient for each convict to have 'a mug of milk with a white loaf in the morning and soup with groats and meat at lunchtime with enough left for supper' (Rucinski, 2009: 337).

In this period, the civil status of Polish convicts and exiles was specified in the Regulations on deported convicts (Ustav o ssyl'nykh) (the 1822 edition) and was similar to that of other citizens.

The position of Polish exiles and convicts was determined after 1830 not only by the severity of their punishment but by their previous social background as well. It is necessary to note that according to Maksimov, nearly 2/3 of people exiled for political offences were members of the aristocracy (Maksimov, 1900: 342). For example, a small group of insurgents were sentenced to 5 years of Siberian exile but retained their social ranks and property. After the term of exile expired they had a right to settle down in Russia's European provinces. This measure concerned, first of all, aristocratic Polish gentry (shliakhetstvo).

There was a broader category of exiles. The group included Poles belonging to various social classes (e.g. the aristocracy (shliakhetstvo), the urban petty bourgeoisie (meshchanstvo) and the peasantry) but sentenced to the forfeiture of property. This category had the most restricted rights. Hence the exiles of this group faced with the most desperate situation in Western Siberia where 'by law, they were forced to remain within 10 versts $(10.67 \mathrm{~km}$ or $6.6 \mathrm{~m})$ of a village or a town that they were to be transported to', Maksimov wrote (Ibid). Still, former aristocrats (shliakhtichi) were in the more favourable circumstances among the exiles, which, as a result, made it possible for them to receive a yearly allowance of 57 roubles from the government, while elderly and disable people were entitled to 114 roubles a year (Ibid). In fact, however, receiving the money due to the exiles was very difficult for Poles. They were constantly dependant on the goodwill of the local authorities that decided whether to pay the allowance or not and it negated their nominal advantage over former middling urbanites (meshchane) and peasants who were not granted the allowance privilege.

Regulations on deported convicts and its numerous editions stipulated social positions of the exiles of this category in detail. For example, it required that Polish exiles should settle either in the already existing villages together with native inhabitants or in newly established settlements (art. 673) (Ustav o ssyl'nykh, 1857). The situation was more beneficial for those exiled Poles who were sent to native peasant communities. Natives had a right to house exiles and receive half of their monetary allowance for four months (art. 677) (Ibid). The amount of the daily monetary allowance paid to exiled Polish offenders was revised by the Finance Ministry every year ${ }^{5}$ and, thus, was subjected to change.

Local administrations were interested in binding exiled settlers to new places at any cost. For example, native inhabitants who got married to women exiles were to be paid 15 roubles in silver without repaying the money to set up house and another 15 roubles as a loan on equal terms (art. 766). Local women of the free estate when getting married to an exile were given 50 roubles in silver as a monetary reward (Ibid).

The term of being classed as an exiled settler was set for 10 years (art. 682). People stripped of rights established in their social estate and exiled under administrative procedures were offered an opportunity to enter the class of state peasants after serving part of their exile term. Nevertheless, 
former exiled convicts were prohibited from returning to European Russia. Regulations on deported convicts (the 1857 edition) stipulated that persons who left the estate of exiled deportees 'had a right to settle down in places on their choice, namely, in all Siberian provinces and regions both in towns and in villages with the knowledge of the local authorities and their consent except in the so called Siberian line, in the Semipalatinsk region as well as in the region of Siberian Kirghizes' (art. 728) (Ustav o ssyl'nykh, 1857).

The end of the term did not automatically change civil statuses of the exiles. The Section On the expenditure on exiles in their assigned stations in Regulations on deported convicts defined the number of exiles obligatorily assigned to a peasant community. The state of affairs was only natural since the released person again became a member of the estate liable for a poll tax (a capitation tax) and, as a result, was fully obliged to pay national and local taxes and carry out compulsory services. It was necessary to receive a written consent from a particular peasant community to become a state peasant (art. 734) (Ibid). Later on, the joining resolution was registered in the local administration and then sent to the provincial Treasury Chamber (Kazennaya palata) to put the newly joined member of the peasant community on the list of taxpayers (rasklad podatei). At the same time the resolution on joining a village community proved to be very costly for the candidate. Some Siberian historians mentioned that 'the joining resolutions were exceedingly expensive' (Solov'ev, 1981: 72).

Besides, those who finished serving their exile terms, but did not receive a right to return to their previous place of residence, had an opportunity either to join the estate of the petty urban bourgeoisie or carry on trade. Yet, a permit for either of these opportunities was often a favour from the local government as over 10 years exiles should 'remain loyal, do the local authorities no wrong' (Ustav o ssyl'nykh, 1857).

After former aristocrats (shliakhtichi), middling urbanites (meshchane) and peasants were excluded from their social classes, their fiscal relations with the government changed. When they arrived to Siberia and settled down in a new place they became liable for specific tax provisions. For example, they were totally exempt from all taxation in the first three years, and in the following seven years, they were to pay half of poll and quit-rent (obrok - a rent payable to one's lord or the government instead of services that might otherwise have been required) tax money. Still, local provincial and district taxes (zemskie podati), as well as peasant community taxes (volostnye podati), were not payable by them. Other specific feature in the taxation policies towards exiles was levying annual 15 kopecks in silver on them into the so-called economic fund for the exiled persons aimed at supporting old and disable exiles (art. 751) (Ibid).

In February 1838, Siberian authorities started granting exiled Poles 40.5-acre plots of land (15 dessiatines). The measure was based on the order from the head of the Third Section (Tretie Otdeleniye of His Imperial Majesty's Own Chancellery) count Alexander Kh. Benckendorff to the Governor General of Western Siberia P.D. Gorchakov. Under the order, 'the 1835 Imperial ordinance to allot state prisoners sent into Siberian exile arable lands near the places of their residence' was to be extended to the 'exiled Polish insurgents'.

The task of carrying out the plan was entrusted by P. Gorchakov to the Tobol'sk Treasury Chamber. The latter submitted a request for information about the Poles forcibly settled in the province to the Tobol'sk dispatching office of the exiled persons (Tobol'sk ekspeditsia o ssyl'nykh). In June 1838, the Economic department in the 
Tobol'sk Treasury Chamber received a 'name register of all Polish insurgents sent into internal exile to the Tobol'sk province since $1832^{\text {'? }}$.

Why did the government begin putting the project into life? The answer is suggested by the internal documents that duplicated circular letters from St. Petersburg. For example, a report by the Tobol'sk Treasury Chamber Economic department said that the land was necessary 'in order to provide them with the means to satisfy their household needs or secure the future of their children born in Siberia by way of cultivating it's.

The plots of land were granted to political prisoners and that was supposed to bind them to Siberia. It should be noted that the idea was supported by the Polish exiles themselves. For example, the Tobol'sk Treasury Chamber received a report by the Kurgan District Court (Zemskii court) that submitted a request from the exiled Poles in the Smolinsk peasant community (Smolinsk volost) to give them the land in one place ${ }^{9}$. Subsequently, the request was granted. Interestingly, the Poles were offered the plot of land which earlier was given to the exiled Decembrists, Rosen, Lorer, Briggen and Nazimov who had left the Kurgan district (Kurgan okrug) by the time ${ }^{10}$. There was an apparent simplicity in the way that Siberian regions developed continuity between various groups of political exiles at different times.

Concerning children of Siberian exiles, those of them who were born before their parents' conviction should have been left in their initial civil estate (art. 767) (Ustav o ssyl'nykh, 1857). However, if children were born while in exile, local officials were to register them in the census records (revizia) (art. 767) while children of the convicts sentenced to hard labour joined the peasantry in peasant communities (volosti) near the hard labour sites (art. 768) (Ibid.).

The period between 1840s and 1850s saw the government still sending Polish convicts into internal exile to Western Siberia. As a rule, they were the members of secret societies or young people who participated in antigovernment protests. For example, the Tobol'sk province in 1857 became the place of exile for former aristocrats and students of Kiev St. Vadimir University, Iosif Rozental' and Antonii Skovronskii, who were sentenced to internal exile for masterminding a peasant uprising in the Kiev province ${ }^{11}$.Their initial term sentencing them to 6.5 years of hard labour in fortified towns (ostrogi) was commuted to internal exile in the remote areas of Siberian provinces. And they were not isolated instances.

Poles settled down across Siberia already in the late 1830s. There were not only exiled convicts among them, but those who moved to Siberia over the Urals executing their professional duty as well. The latter were not yet numerous servicemen. Many exiles were sent to Tobol'sk. There were also Polish officials in the town. Exiled Ju. Rucinski, for example, mentioned Kuz'minskii and well-known A.F. KozelloPoklevskii(Poklevskii-Kozell) (the book mentions him as Kozhello-Pakhlevskii) in his memoirs, the officers for special assignments under Western Siberia Governor General Prince Gorchakov (Rucinski, 2009: 330). A.F. Kozello-Poklevskii had different positions in the Tomsk provincial government since 1834 , and in 1836 , he was taken on the staff of the Western Siberia Governor General. Poles were officers guarding exiles sent to Siberia, shopkeepers, and craftsmen. Eastern Siberia exiles were sent to Nerchinsk works. Some of them were soldiers in the local battalion and invalid company (invalidnaia rota) while others had to serve sentences of hard labour. 'The variety of social backgrounds shaped their future. One example cited that some got married to local women and became Siberians once and for all. Others, struggling to fight poverty, had to work as day labourers for peasants. Few craftsmen were 
in a less difficult situation as their goods were in demand on the local market' (Ibid.: 385). This description by a contemporary indicates changes in the national identity since some exiles chose to become a part of Siberian society accepting its standards and rules. Meanwhile, there was a group of Polish exiles who clung to the hope of returning to their homeland. As a result, they retained certain elements of the Polish national and religious lifestyle.

Recordkeeping papers stored in the archives of the Russian State Historical Archives (St. Petersburg) suggest a dynamic picture of the Polish population in the $1850-60 \mathrm{~s}$ of the $19^{\text {th }}$ century according to the total number of Catholics in the area ${ }^{12}$. For example, the Second Siberian committee recorded nearly 6,250 Catholics in the towns of Western Siberia and Eastern Siberia (except Tobol'sk) in 1852 who had parish churches in Irkutsk and Tomsk. It is important to note that the largest parish community belonged to the Tomsk parish (2.4 thousand people) ${ }^{13}$. It was, certainly, raw data that included both exiles and free inhabitants.

When we speak of such a considerable number of Poles in Siberia we inevitably have to deal with the issue of their economic activities. Unfortunately, there are very few sources on the subject. The reason for this was that under the effective legislation persons, 'sentenced to hard labour or settlement in internal exile and stripped of all rights of their social estate, could not purchase any real property' (art. 773). However, the article did not limit their right to own property. In this case, contracts for land and house purchases were concluded under the name of the Dispatching office of exiled persons (art. 774-775) (Ustav o ssyl'nykh, 1857). Thus, Polish exiles were integrated into Siberia's economic life. The situation is explained by the fact that real property could be registered in their wives' names who remained free, but followed their husbands to exile. In other cases, enterprises could be formally run on behalf of Siberian manufacturers who posed as a cover. At any rate, the few information sources still permit some reconstruction of their activities.

The life of former confederates and convicts sent to Siberian exile in the second quarter of the 19 th century is depicted only in indirect sources. One instance given in S.V. Maksimov's work reveals that descendants of bar confederates were scattered throughout Siberia. There were two villages founded by the latter in Western Siberia near Semipalatinsk (Maksimov, 1900: 337). Panovskii, the head of the peasant community (volostnoi golova) in Tarskii district (Tara uezd) in the Tobolsk province, had a confederate grandfather. The brothers Grabianskie, trading middle class urbanites (meshchane) in Tara itself, had a Polish father. There were the Kostyletskies, the Yanovskies, the Khlynovskies and others (Ibid.).

Once in Siberia, exiled Poles tried to settle down, make their life more comfortable and earn their living. They succeeded quite well. Good education of Polish exiled settlers made it possible for them to embark on manufacturing and trading activities as ancillary staff. Their national unity helped them be hired as clerks in factory offices and in administrations of peasant communities. In the $1840 \mathrm{~s}$, some of them managed to secure permissions for public service, though they were offered positions of minor clerks. In one instance, Pavel Tseplinskii exiled in 1832 was a junior clerk (kantselyarist) in 1844, papers from the Omsk police chief reported ${ }^{14}$. At the same time, Adolf Yanushkevich, Adam Mitskevich's friend, worked as a junior clerk in the Omsk Border Chancery (pogranichnaya kantselyariya) ${ }^{15}$. Right was S.V. Maksimov, who wrote in the late $19^{\text {th }}$ century, that 'where one Pole tightly secured a position, there was an opportunity to draw support for another Pole' (Ibid.: 347). 
There was a mention made above that the land granting campaign was launched in all Siberian provinces in the late 1830s. Still, it is important to note that its scope was limited. Under a name register from the local dispatching office of exiled persons, plots of land were due to 41 insurgent Poles in the Tobol'sk province ${ }^{16}$. The register analysis suggests that only 17 people of the total number did not change their place of residence between 1832 and 1838 since they came to the Tobol'sk province ${ }^{17}$. Many exiles had to move from place to place and this led to their impoverishment. Plots of land granted by the Treasury Chamber offered them potential sources of income as the plots were located near settlements they were registered in. Poles, for instance, could well let the lands out to local inhabitants as pastures or hayfields.

Great popularity was gained among Siberian manufacturers by technically qualified Poles who facilitated various technical innovations. Unintentionally, they were involved in many developing branches of manufacturing industry. Poles, for instance, turned their attention to the products of Siberian pine nut enterprises that were widely spread in Western and in Eastern Siberia.

A more successful cedar oil producing business belonged to Pole Mikhail Morachevskii. Hewasalieutenant(poruchik) in the Arensburgskii battalion of the internal guard before exile to Siberia in 1831. After he was transported to the town of Ishim he got married to a rich widow (Fil', 2002: 11). The capital received through his wife's dower must have been invested into an oil mill. The products from his oil mill were brought to Moscow and excited much interest among the local merchants (Maksimov, 1900: 347). In 1859, Morachevskii and his family left Siberia and, as a result, his enterprise shut down.

Manufacturing and selling cedar oil to European Russia earned Poles in Western Siberia a large income. The scope of their business is demonstrated through an example when an oil mill owned by Savichevskii, a Polish man in the village Shembelik of the Irkutsk province, produced 12,000 roubles worth of oil in 1859 (Ibid.: 348).

The cedar oil generated enormous demand in Russia as it was added to olive low-grade oil that was used in icon lamps in Orthodox churches and houses. Earlier olive oil was diluted with ersatz oil products (mainly, with rapeseed oil) but Siberian cedar oil turned out to have more suitable properties.

Poles set up enterprises producing cheese, soap, candles and cigars of Mongolian and Nerchinsk tobaccos. They also made contributions to beekeeping and horse breeding. Farming and craft activities made life fairly comfortable for their families. However, the enterprises rarely lived longer than their founders. The situation resulted from the position adopted by Poles. Most of them manufactured various products to support a comfortable lifestyle rather than to get into the market. Hence their products were chiefly sold in western provinces.

Most Polish exiles experienced financial difficulties in the 1830s. In particular, elderly people who under the Regulations on deported convicts were registered as the disabled were supported by their relatives. Thus, the above mentioned Decembrist Lorer who served his exile sentence in the town of Kurgan in the second half of the 1830s wrote in his memoirs about Kirian Voronetskii, an exiled prince, who lived in the same area and whom Lorer called 'a pitiable pauper' (Lorer, 1984: 172). For others, the sources of livelihood were money, sent from their home country by relatives. For instance, archives preserved receipts signed by Polish exiles who received money and parcels sent to them through the police ${ }^{18}$.

Having no opportunities to settle down in Siberia, they immediately exercised their right to return to the home country. 
At the same time, the descendants of bar confederates and participants in the uprising led by T. Kostyushko (kostyushkovtzy) were more successful. They were rather prosperous and respected. Some of them, as we can see, held elected positions in peasant communal administrations (vybornii) while others managed to become government officials. As the exiles and their descendants lived a life of comfort, few of them sought a return to the homeland. Thus, S. Maksimov believed that 'Paul I's edict hardly affected most exiled convicts' (Maksimov, 1900: 339). A similar situation developed in the mid1810s. At that time Siberian officials learnt that Polish prisoners of war who previously served in Napoleon's army were granted a permission to return to their native country. Still, 'there were 900 people who had served in the cavalry and had been conscripted into Cossacks... while the lifelong service in Cossacks units was chosen by 160 people' (Ibid.).

The Poles who remained in Siberia were also linked to their new home with family ties since many of them got married to Siberian women. Their children had difficulties to use Polish already in the first generation. Moreover, some did not speak Polish at all and considered themselves to be native Siberians. Hence the Siberian diaspora that emerged from the late $18^{\text {th }}$ to $19^{\text {th }}$ centuries became assimilated into Western Siberia.

\section{Results}

Thus, the first half of the $19^{\text {th }}$ century witnessed the Polish community forming in Western Siberia. Its primary sources were prisoners of war and exiled rebels who were involved in anti-government uprisings. Siberian Poles came from diverse social backgrounds, but they were predominantly aristocrats denied various personal and hereditary rights and privileges, and classed subsequently as state peasants. The government wanted to firmly attach the status to the people giving them land, but farming did not become essential to the exiles. Personal qualities and relatively loyal attitude of Siberian officials allowed many of them to be granted a right to become civil servants. Meanwhile others were supported by relatives or by the state.

Under the amnesty declared early in the reign of Alexander II, the exiles regained their previous rights and had chances to return to their home country. It caused an outflow of Poles from Western Siberia but already a decade later the Siberian diaspora grew dramatically as new exiles arrived sentenced for their role in the 1863 uprising.

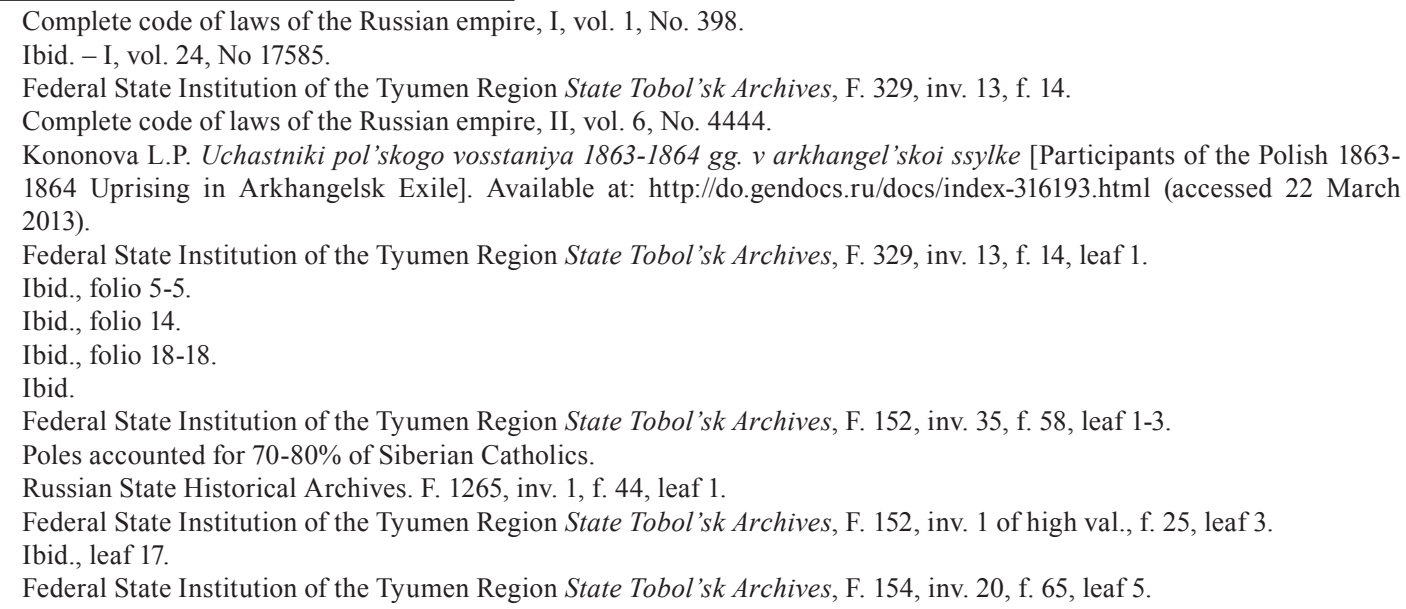


Federal State Institution of the Tyumen Region State Tobol'sk Archives, F. 154, inv. 20, f. 65, leaves 6-10. Federal State Institution of the Tyumen Region State Tobol'sk Archives, F. 152, inv. 1 of high val., f. 25.

\section{References}

Gerasimov, B. (1918). Polish exiles in the Semipalatinsk region (Brief historical overview), In Zapiski Semipalatinskogo podotdela Zapadno-Sibirskogo otdela Russkogo geogreficheskogo obshchestva [Proc. of the Semipalatinsk Section in the Western Siberian Department of the Russian Geographical Society], XII, Semipalatinsk, 108.

Konovalova, L.P. Uchastniki pol'skogo vosstania 1863-1864 gg. V arkhangel'skoi ssylke [Participants of the Polish 1863-1864 Uprising in the Arkhangelsk Exile]. Available at http://do.gendocs. ru/docs/index-316193.html (accessed 22 March 2013).

Lorer, N.I. Zapiski dekabrista [Notes by a Decembrist]. Irkutsks, 1984. 416 p.

Lorer, N.I. Notes on my Time. Memoirs of the Past [Zapiski moego vremeni. Vospominania o proshlom], In Zapiski dekabristov [Decembrists' memoirs]. Moscow, 1988, 315-545.

Maksimov, S.V. Sibir' i katorga [Siberia and Hard Labour]. St. Petersburg, 1900. 488 p.

Rucinski, Yu. Konarshchik. Vospominania iz Sibiri: Memuary, ocherki, dnevnikovye zapisi pol'skikh ssyl'nykh v Vostochnuiu Sibir' pervoi poloviny XIX stoletia [Reminiscences of Siberia: Memoirs, Essays, Diary Notes of Polish Exiles to Eastern Siberia in the First Half of the $19^{\text {th }}$ Century]. Irkutsk, OOO Artizdat, 2009, 325-476.

Skubnevskii, V.A. (2009). Academic and Cultural Figures of Polish Descend in Western Siberia in the $19^{\text {th }}-$ Early $20^{\text {th }}$ Centuries, In Stereotipy $i$ natsionalnye sistemy tsennostei $v$ mezhkul'turnoi kommunikatsii [Stereotypes and National Systems of Values in Intercultural Communication], 1, St. Petersburg - Olsztyn, Nevski Institute of Language and Culture Publ., 180-185.

Solov'eva, E.I. Promysly sibirskogo krest'ianstva v poreformennyi period [Economic Activities of Siberian Peasants in the Post-Reform Period]. Novosibirsk, 1981, 329 p.

Ustav o ssyl'nykh [Regulations on Deported Convicts], In Svod zakonov Rossiiskoi imperii [Code of Laws of the Russian Empire]. Vol. XIV, St. Petersburg, 1857.

Fel'dman, D.Z. (2005). K istorii poiavlenia kreshchennykh evreev v Moskovskom gosudarstve XVII v. [On the History of Emergence of Baptized Jews in the Grand Duchy of Muscovy in the $17^{\text {th }}$ Century], In Drevnia Rus'. Voprosy Medievistiki [Ancient Russia. Medieval Studies]. 4 (22).

Fil', S. (2002). Poliaki v Ishimskoi ssylke v pervoi polovine XIX veka [Poles in Ishim exile in the first half of the 19th cen.], In Korkina sloboda. Kraevedcheskii al'manakh [Korkina sloboda. Regional ethnographic anthology], 4, Ishim, 9-14.

Shaidurov, V.N. (2009). Pol'skaia obshchina Zapadnoi Sibiri v kontse XIX - nachale XX v.: osobennosti formirovania i razvitia [Polish Community in Western Siberia in the late $19^{\text {th }}-$ Early $20^{\text {th }}$ Centuries: Formation and Development Features], In The News of Altai State University, 3 (4), 253258.

Shostakovich, B.S. Istoria poliakov v Sibiri (XVII - XIX vv.) [History of Poles in Siberia (17-19 cen.)]. Irkutsk, 1995, 165 p.

Shostakovich, B.S. Konarshchik Yustisian Rucinski i ego vospominania o sibirskoi ssylke [Konarshchik Yustisian Rucinski and his Memoirs of Siberian exile], In Vospominania iz Sibiri: Memuary, ocherki, dnevnikovye zapisi pol'skikh ssyl'nykh v Vostochnuiu Sibir' pervoi poloviny XIX 
stoletia [Reminiscences of Siberia: Memoirs, Essays, Diary Notes of Polish exiles to Eastern Siberia in the First Half of the $19^{\text {th }}$ Century]. Irkutsk, OOO Artizdat, 2009, 301-324.

\title{
К вопросу о формировании \\ и развитии сибирской полонии \\ в первой половине XIX века
}

\author{
В.Н. Шайдуров \\ Национальный минерально-сырьевой университет \\ «Горныйџ» \\ Россия, 199106, Санкт-Петербург, \\ 21-я линия Васильевского острова, 2
}

\begin{abstract}
В исторической науке России и Польши большое внимание уделено изучению формирования и развития полонии вне традиционного места проживания. Польские общины активно формировались в результате реализации карательной политики государства с конца ХVIII века. Одним из регионов, принявших значительную часть выходцев из польских земель, стала Сибирь. Однако в историографии основное внимание традиционно уделено изучению польской общинь во второй половине ХІХ века, тогда как исследований по начальному периоду ее становления 6 отдельных сибирских губерниях крайне мало. В статье решена исследовательская задача: на основании материалов различных архивов определены основные особенности формирования и развития сибирской полонии в дореформенный период.

Ключевые слова: польская община, Сибирь, Тобольская губерния, Томская губерния, дореформенный период, ХІХ век, польские восстания, ссылка, полицейский надзор, хозяйственные занятия.
\end{abstract}

Научная специальность: 07.00.00 - исторические науки. 